\title{
Pengaruh Motivasi Kerja Terhadap Kinerja Pegawai Pada Kantor Pertanahan di Lingkungan Kantor Wilayah Badan Pertanahan Nasional Provinsi Jawa Barat
}

\author{
Biller Panjaitan \\ Email: billerpanjaitan@gmail.com
}

\begin{abstract}
The objectives of this research are: 1) to reveal descriptions of work motivation and employee's performance of the Regional West Java Land Office, 2) to test hypothesis of the relationships and influences among work motivation and employee's performance.The type of this research are descriptive and verificative research. The method used of this research is survey method.Sample size are 219 employees of the Regional West Java Land Office who are sampled by proportional stratified random sampling method. The data used in this research were primary data collected by questioners. The analysis method used in this research are descriptive and hypothesis testing analysis with the analysis tool using the structural equation modeling ( SEM ) and processed by LISREL 8.51 ( Linier Structural Relationship ) programme 8.51 for windows software. The results of descriptive analysis indicate that the work motivation and employee's performance were categorized 'good', however work motivation still needs to be improved. Based on the results of hypothesis testing indicate that there was positive and significant relationship between the independent variables It means have positive sinergy with work motivation to increase employee's performance in the Regional West Java Land Office. Based on descriptive and verificative analysis, it is necessary to recommend that decision makers of the Regional West Java Land Office have to determine policies on developing human resources, on the work motivation therefore in turn it will effect on employee's performance improvement.
\end{abstract}

Keywords: work motivation, employee's performance.

\begin{abstract}
Abstrak. Tujuan penelitian ini adalah: 1) Mengungkap deskripsi motivasi kerja dan kinerja karyawan Kantor Pertanahan Daerah Jawa Barat, 2) menguji hipotesis hubungan dan pengaruh antara motivasi kerja dan kinerja karyawan. Jenis penelitian ini adalah deskriptif. dan penelitian verifikatif. Metode yang digunakan dalam penelitian ini adalah metode survei. Ukuran sampel adalah 219 pegawai Kantor Pertanahan Regional Jawa Barat yang diambil sampelnya dengan metode proportional stratified random sampling. Data yang digunakan dalam penelitian ini adalah data primer yang dikumpulkan oleh kuesioner. Metode analisis yang digunakan dalam penelitian ini adalah analisis deskriptif dan pengujian hipotesis dengan alat analisis menggunakan structural equation modelling (SEM) dan diolah dengan program LISREL 8.51 (Linier Structhip Relationship) 8.51 for windows software. Hasil analisis deskriptif menunjukkan bahwa motivasi kerja dan kinerja karyawan dikategorikan 'bagus', namun motivasi kerja masih perlu ditingkatkan. Berdasarkan hasil pengujian hipotesis menunjukkan bahwa ada hubungan positif dan signifikan antara variabel independen artinya memiliki sinergi positif dengan motivasi kerja untuk meningkatkan kinerja karyawan di Kantor Pertanahan Daerah Jawa Barat. Berdasarkan analisis deskriptif dan verifikatif, perlu untuk merekomendasikan bahwa pengambil keputusan dari Kantor Pertanahan Daerah Jawa Barat harus menentukan kebijakan pengembangan sumber daya manusia, pada motivasi kerja sehingga pada gilirannya akan berdampak pada peningkatan kinerja karyawan.
\end{abstract}

Kata kunci: motivasi kerja, kinerja karyawan.

\section{A. PENDAHULUAN}

\section{Latar Belakang Penelitian}

Pelayanan lembaga /Instansi

Pemerintah antara lain instansi pertanahan sudah lama menjadi topik sorotan masyarakat bahkan hujatan karena kinerjanya belum seperti apa yang diharapkan oleh masyarakat Menyikapi keluhan-keluhan masyarakat yang masih tinggi terhadap pengurusan sertifikat hak atas tanah, kelambatan penyelesaian sertifikat hak atas tanah maka sangat diperlukan usaha peningkatan pelayanan penyelesaian penerbitan sertifikat hak atas tanah yang 
merupakan kepastian hukum kepemilikan hak atas tanah sangat perlu proses penyelesaian sertifikat hak atas tanahnya diproses dengan cepat, akurat dan tepat waktu.

Tuntutan masyarakat saat ini terhadap pelayanan publik pemerintah di berbagai sektor publik, menyebabkan semakin intensif pula campur tangan pemerintah dalam segala aspek kehidupan masyarakat. Pemerintah sebagai penyedia berbagai barang dan jasa publik (public goods), dibidang pertanahan dalam hal ini Badan Pertanahan Nasional yang melakukan pelayanan pengurusan sertifikat hak atas tanah harus merespon setiap perubahan tersebut sehingga legitimasi pemerintahan tetap terpelihara.

$$
\text { Penyelesaian }
$$

penerbitan

sertifikat hak atas tanah tersebut dikerjakan atau diterbitkan oleh lembaga pemerintah yakni Badan Pertanahan Nasional, yang melayani masyarakat seluruh wilayah negara Republik Indonesia dengan perangkat organisasi vertikal didaerah yaitu Kantor Wilayah Badan Pertanahan Nasional Provinsi dan Kantor Pertanahan Kabupaten/Kota di wilayah kabupaten atau kota.

Kantor Pertanahan di lingkungan Kantor Wilayah Badan Pertanahan Nasional Provinsi Jawa Barat, merupakan perangkat Pemerintah Pusat (Badan Pertanahan Nasional) yang ada di daerah sebagai pelaksanaan tugas dan fungsi Kantor Wilayah Badan Pertanahan Nasional Provinsi Jawa Barat mengacu pada Keputusan Kepala BPN Provinsi Tahun 1989 tentang organisasi dan tata kerja Kanwil BPN dan Kantor Pertanahan Kabupaten/Kota yang diperbaharui dengan peraturan Kepala Badan Pertanahan Nasional no. 3 dan No 4 Tahun 2006.

Sumber daya manusia merupakan faktor penentu bagi suatu organisasi atau kantor. Dalam menjawab tantangan diatas, instansi pemerintah dalam hal ini kantor pertanahan dapat melakukan upaya pengelolaan sumber daya manusia dengan lebih baik.

kerja pegawai,untuk mendukung pencapaian kinerja pegawai, peranan motivasi sangatlah penting sebagai kekuatan yang ada dalam diri individu yang akan menggerakkan orang-orang untuk melakukan sesuatu dengan lebih bersemangat terutama dalam motivasi kerja yang berperan bagi prestasi kerja pegawai (Donald, 2003). Beranjak dari paparan dan fakta di atas, maka tema sentral penelitian ini adalah: "Bagaimana "Motivasi Kerja berpengaruh terhadapn Kinerja pagawai pada Kantor Pertanahan di lingkungan kerja Kantor Wilayah Badan Pertanahan Nasional Propinsi Jawa Barat"

\section{Identifikasi Masalah}

Di era reformasi saat ini dituntut adanya pelayanan prima oleh instansi pemerintah yang mengharuskan pemerintah harus merubah diri, responsif terhadap harapan masyarakat, strategi yang bagus belaka belumlah memadai. Pemimpin yang handal ,motivasi kerja pegawai, yang mampu merespon tuntutan eksternal dan internal sangat dibutuhkan oleh instansi pemerintah sebagai pelayan publik. Dalam situasi seperti ini sangat diperlukan motivasi kerja pegawai yang tinggi, dalam penyelesaian pekerjaan secara cepat dan tepat serta akurat.

Di kantor Pertanahan di Lingkungan Kantor Wilayah Badan Pertanahan Nasional Propinsi Jawa Barat perubahan yang diinginkan adalah perubahan yang mempengaruhi kebutuhan karakter dan perilaku sumber daya manusia (SDM) yang 
handal dan motivasi kerja pegawai dalam rangka meningkatkan pelayanan kepada masyarakat.

Demikian juga Mark E.Furman (1997:8), juga mengemukakan bahwa "motivasi sebagai aspek psikologis individu merupakan faktor lain yang dapat meningkatkan prodiktivitas kerja. Motivasi dapat memacu pegawai untuk bekerja keras sehingga dapat mencapai tujuan mereka. Hal ini akan meningkatkan produktivitas kerja sehingga berpengaruh terhadap pencapaian tujuan organisasi.

Dengan tantangan kantor pertanahan yang semakin kompleks memerlukan suatu upaya konsolidasi, agar instansi publik yang mampu melayani masyarakat dengan baik. Mengacu pada konsep motivasi, manajemen kantor pertanahan, perlu mewujudkan motivasi kerja yang tinggi berkontribusi pada kinerja kantor pertanahan.Sementara itu, saat ini kinerja pegawai kantor pertanahan belum optimal Manajemen telah berupaya membentuk motivasi kerja pegawai sesuai tuntutan masyarakat pemohon sertifikat hak atas tanah. Namun di sisi lain masih menjadi pertanyaan mengenai "seberapa besar pengaruh motivasi kerja pegawai terhadap kinerja pegawai.

Beranjak dari paparan diatas tentang masalah yang dihadap kantor pertanahan, maka variabel motivasi kerja terhadap kinerja pegawai pada kantor pertanahan yang menjadi tema sentral penelitian ini, maka penelitian ini difokuskan pada upaya mengkaji: Pengaruh motivasi kerja terhadap kenerja pegawai pada kantor pertanahan di lingkungan kantor wilayah badan pertanahan nasional provinsi Jawa Barat.

\section{Rumusan Masalah}

Berdasarkan

uraian menyeluruh tentang aspek situasional dan kondisional serta identifikasi masalah pada latar belakang penelitian di atas, maka dapat dirumuskan permasalahan pokok penelitian ini yakni sebagai berikut:

1. Bagaimana tentang motivasi kerja dan kinerja pegawai pada Kantor Pertanahan dalam lingkungan Kanwil Badan Pertanahan Nasional Propinsi Jawa Barat.

2. Seberapa besar pengaruh motivasi kerja terhadap kinerja pegawai.

\section{Maksud Penelitian}

Secara umum penelitian ini bermaksud untuk mengungkap tentang pentingnya pemahaman tentang pengaruh motivasi kerja dengan kinerja pegawai pada Kantor Pertanahan dalam lingkungan Kanwil Badan Pertanahan Nasional Propinsi Jawa Barat.

\section{Tujuan Penelitian}

Adapun tujuan penelitian ini yang ingin dicapai dalam penelitian ini adalah untuk :

1. Menyajikan hasil kajian tentang tingkat motivasi kerja, dan kinerja pegawai pada Kantor Pertanahan dalam lingkung wilayah kerja Kanwil Badan Pertanahan Nasional Propinsi Jawa Barat.

2. Mengungkapkan seberapa besar pengaruh motivasi kerja terhadap kinerja pegawai pada Kantor Pertanahan dalam lingkungan wilayah kerja Kanwil Badan Pertanahan Nasional Propinsi Jawa Barat.

\section{Kegunaan Penelitian}

Hasil penelitian ini mempunyai kegunaan secara teoritis dan kegunaan praktis atau operasional, secara rinci kegunaan hasil penelian tersebut dijelaskan sebagai berikut:

\section{Kegunaan Teoritis}


Secara teoritis diharapkan hasil penelitian ini berguna dalam pengembangan ilmu ekonomi manajemen khusus manajemen sumber daya manusia pada organisasi pada Kantor Pertanahan di lingkungan kerja Kanwil Badan Pertanahan Nasional Propinsi Jawa Barat.sebagai berikut :

(1) Sebagai bahan pengembangan literatur bidang ilmu manajemen dalam hal konsep pengukuran variabel independen motivasi kerja.

(2) Sebagai bahan pengembangan literatur bidang ilmu manajemen dalam hal konsep pengukuran variabel dependen kinerja pegawai pada Kantor Pertanahan di lingkungan kerja Kanwil Badan Pertanahan Nasional Propinsi Jawa Barat.

\section{Kegunaan Operasional}

Sebagai bahan pertimbangan bagi organisasi dalam upaya untuk meningkatkan motivasi kerja dan kinerja pegawai Kantor Pertanahan di lingkungan kerja Kanwil Badan Pertanahan Nasional Propinsi Jawa Barat.

\section{B. KAJIAN PUSTAKA}

\section{Pengertian Motivasi Kerja}

Motivasi merupakan satu istilah yang artinya dapat berbeda-beda, tergantung dari sudut pandang mana kita melihatnya. Menurut Hersey, Blanchard, and Johnson (1996:27), "The motivation of people depends on the strength of their motives. Motives are sometimes defined as needs, wants, drives, or impulses within the individual!", yang berarti bahwa motivasi seseorang dipengaruhi atau tergantung dari kuatnya motif atan alasan-alasan untuk melakukan sesuatu. Motif atau alasan bisa karena kebutuhan-kebutuhan, keinginan- keinginan, dorongan dari orang tersebut.

Akan tetapi dilihat dari sudut pemeliharaan hubungan dengan para pegawai maka motivasi merupakan bagian yang penting. Menurut Nawawi (1998 : 351) kata motivasi (motivation) kata dasarnya adalah motive yang berarti dorongan sebab atau alasan seseorang melakukan sesuatu. Dengan demikian motivasi berarti suatu kondisi yang mendorong atau menyebabkan seseorang melakukan sesuatu perbuatan/ kegiatan yang berlangsung secara sadar.

\section{Teori Motivasi}

Teori mengenai motivasi banyak diungkapkan oleh para ahli, dan teoriteori tersebut pada garis besarnya dapat dikelompokkan menjadi dua kelompok yaitu, teori kepuasan (content theory) dan teori proses (process theory). Teori motivasi kepuasan mendasarkan pada faktor-faktor kebutuhan dan kepuasan individu sehingga mereka mau melakukan aktifitasnya. Teori ini mencari tahu tentang kebutuhan apa yang dapat memuaskan dan dapat mendorong semangat kerja seseorang. Sedangkan teori proses berkaitan dengan bagaimana motivasi itu terjadi atau bagaimana perilaku itu digerakkan.

Selengkapnya teori-teori motivasi dimaksud dapat diklasifikasikan sebagai berikut :

Tabel 1. Klasifikasi Teori Motivasi

\begin{tabular}{|l|l|l|}
\hline Jenis & Karakteristik & Teori \\
\hline & Berkaitan & 1. Teori \\
& dengan faktor- & Hirarki \\
& faktor yang & Kebutuhan \\
Teori & membangkitka & 2. Teori \\
Kepuasa & n atau memulai & Dua Faktor \\
n & perilaku & 3. Teori \\
& & Kebutuhan \\
& & Prestasi \\
& & 4. Teori \\
& & ERG \\
\hline
\end{tabular}




\begin{tabular}{|l|l|l|}
\hline & Berkaitan & 1. Teori \\
& dengan & Penghargaa \\
& bagaimana & n \\
Teori & perilaku & 2. Teori \\
Proses & digerakkan, & Keadilan \\
& diarahkan & 3. Teori \\
& didukung atau & Penguatan \\
& dihentikan & 4. Teori \\
& & Penetapan \\
& & Tujuan \\
\hline
\end{tabular}

Teori Motivasi Prestasi (Mc. Clelland)

Teori ini menyatakan bahwa seseorang pekerja memiliki energi potensial yang dapat dimanfaatkan tergantung pada dorongan motivasi, situasi, dan peluang yang ada. Kebutuhan pekerja yang dapat memotivasi gairah kerja adalah, kebutuhan akan prestasi, kebutuhan akan kekuasaan dan kebutuhan akan afiliasi yang dikemukakan dalam bentuk 'rumus' yaitu : need,for achievement (n.Ach), need for power (n.Pow), dan need for Affiliati on (n.Aff).

1) need,for achievement (n.Ach), kebutuhan yang kuat untuk berprestasi, dorongan untuk berhasil yang berkaitan dengan sejauh mana orang tersebut termotivasi untuk melaksanakan tugasnya.

Tidak ada manusia yang senang jika dikatakan 'telah gagal. David McClelland (1961:17) mengemukakan enam karakteristik orang yang mempunyai motivasi berprestasi tinggi, yaitu :

- $\quad$ Memiliki tingkat tanggung jawab pribadi yang tinggi,

- $\quad$ Berani mengambil dan memikul resiko

- Memiliki tujuan yang realistik,

- Memiliki rencana kerja yang menyeluruh dan berjuang untuk merealisasikan tujuan,

- Memanfaatkan umpan balik yang konkrit dalam semua kegiatan yang dilakukan, dan
- Mencari kesempatan untuk merealisasikan rencana yang telah diprogramkan.

2) need for Affiliation (n.Aff yaitu hasrat untuk bersahabat dan berhubungan antar pribadi yang ramah untuk mengenal lebih dekat rekan kerja, kebutuhan dimana predikat manusia sebagai mahluk sosial yang memiliki keinginan untuk disenangi, dicintai, kesediaan bekerjasama, iklim bersahabat, dan saling mendukung dalam organisasi.

3) need for power (n.Pow), merupakan kebutuhan akan kekuasaan, serendah apapun jabatan dan kedudukan seseorang dalam organisasi, ia tetap ingin. 'berkuasa' dan berpengaruh terhadap orang lain, lebih menyukai persaingan dan berorientasi pada status/jabatan.

Teori kebutuhan berprestasi dari Mc Clleland sangat relevan digunakan dalam penelitian itu yang berlaku di Kantor Pertanahan sebagai suatu organisasi untuk meningkatkan kinerja organisasi melalui kinerja individu anggota organisasi dengan mengamati motivasi kebutuhan berpotensi tinggi dari seseorang pegawai dapat lebih mudah diamati, diketahui ,dikaitkan dengan pelaksanaan pekerjaan pegawai.

\section{Kinerja Pegawai}

Konsep kinerja banyak di kemukakan oleh para pakar-pakar. Menurut Gibson, Invancevich \& Donnelly (1997:118), kinerja adalah tingkat keberhasilan dalam melaksanakan tugas dan kemampuan untuk mencapai tujuan yang telah ditetapkan.

Kinerja suatu organisasi erat kaitannya dengan hasil yang telah dicapai oleh organisasi yang bersangkutan melalui proses tertentu. Pendapat yang lain dikemukakan oleh 
Bernardine dan Russell (1993 : 147) bahwa :

Performance is defined as the record of outcomes produced an a specific job function or activity during a specific time period. (Kinerja didefinisikan sebagai catatan mengenai outcome yang dihasilkan dari fungsi yang dihasilkan dari fungsi suatu pekerjaan tertentu atau kegiatan selama selama kurun waktu tertentu ).

Selanjutnya Bernardine \& Russell (1993 : 333) mengemukakan bahwa terdapat enam kriteria nilai-nilai kinerja yang dapat diukur yang terdiri dari :

1) Kualitas (Quality) : Tingkat yang dicapai dari proses atau hasil yang diperoleh pada suatu kegiatan mendekati kesempurnaan, dalam bentuk yang dapat menyesuaikan dengan suatu cara yang ideal dalam melakukan kegiatan atau kegiatankegiatan yang sesuai dengan tujuan.

2) Kuantitas (Quantity):Jumlah yang dihasilkan, ditunjukan dalam setiap ukuran dengan nilai dollar/rupiah, jumlah dalam unit, jumlah putaran atau siklus kegiatan yang lengkap.

3) Ketepatan Waktu (Timeliness):Tingkat kelengkapan yang dicapai dalam suatu kegiatan atau hasil yang diperoleh/dicapai pada waktu tercepat yang diinginkan/diperlukan dari sudut pandang baik hubungannya dengan hasil yang lain, maupun memaksimalkan waktu yang tersedia untuk kegiatan-kegiatan yang lain.

4) Efektifitas Biaya (Cost effectiveness) : Tingkat atau sejumlah penggunaan sumber daya organisasi (seperti manusia, anggaran, teknologi, material) secara maksimal untuk memperoleh keuntungan paling tinggi atau mengurangi kerugian setiap unit atau hal-hal yang merugikan dalam penggunaan suatu sumber daya.

5) Keperluan atas Pengawasan (Need for supervision) :Tingkat atau jumlah yang dapat dihasilkan pegawai dalam suatu fungsi tugas tanpa meminta bantuan dari pengawas atau tanpa intervensi pengawas untuk mencegah hal-hal merugikah hasilnya.

6) Interpersonal impact : Tingkat kenaikan kebutuhan pegawai mengenai perasaan harga diri, nama baik, dan kerjasama antara teman kerja dan bawahan.

Dari beberapa pengertian kinerja tersebut di atas dapat disimpulkan bahwa kinerja merupakan prestasi yang dihasilkan seorang pegawai atau kelompok kerja baik secara kualitatif maupun kuantitatif dalam melaksanakan tugas dan tanggung jawab yang dimilikinya.

\section{Pengaruh Motivasi Terhadap Kinerja Pegawai}

Motivasi mempunyai peranan penting bagi seseorang yang mempunyai tanggung jawab dalam suatu organisasi untuk menggerakkan, mengerahkan dan mengarahkan segala daya dan potensi tenaga kerja dalam batas-batas kemampuan manusia dengan bantuan sarana-sarana dan fasilitas lainnya berupa peralatan, uang. material dan metode. Produktivitas suatu organisasi dipengaruhi oleh banyak faktor seperti kesempatan memperoleh pendidikan dan pelatihan tambahan, penilaian prestasi kerja yang adil, rasional dan obyektif; sistem imbalan dan berbagai faktor lainnya. Motivasi dan kepuasan kerja merupakan bagian dari berbagai faktor tersebut. Akan tetapi dilihat dari sudut pemeliharaan hubungan dengan 
para pegawai maka motivasi merupakan bagian yang penting.

David McClelland, seorang ahli psikologi dari masyarakat Universitas Harvard, Amerika Serikat. Dalam teori motivasinya dikemukakan bahwa produktivitas seorang sangat ditentukan oleh "virus mental" yang ada pada dirinya. Virus mental adalah kondisi jiwa yang mendorong seseorang untuk mampu mencapai prestasinya secara maksimal. Virus mental yang dimaksud adalah Achievement Motivation. Motivasi berprestasi dapat diartikan sebagai suatu dorongan dalam diri seseorang untuk melakukan atau mengerjakan suatu kegiatan atau tugas dengan sebaik-baiknya agar mencapai prestasi dengan terpuji. Hal ini sesuai dengan pendapat Jhonson, (1984:9) yang mengemukakan bahwa : "Achievement motive is impetus to do well relative to some standard of excellence".

Pegawai sebagai ujung tombak yang memberikan pelayanan terbaik kepada masyarakat. Pegawai-pegawai yang bekerja pada kantor pertanahan mempunyai berbagai kebutuhan, tujuan, harapan yang harus dicapainya.

Untuk menyelesaikan pekerjaan penerbitan sertifikat hak atas tanah dengan tepat waktu pada kantor pertanahan di lingkungan Kantor Wilayah Badan Pertanahan Nasional Propinsi Jawa Barat tentunya memerlukan pegawai yang motivasi dalam rangka meningkatkan pelayanan kepada masyarakat .

\section{Hipotesis Penelitian}

Berdasarkan uraian teori dan kerangka pemikiran yang diajukan, maka hipotesis dalam penelitian ini adalah :

1. Motivasi Kerja dan kinerja pegawai pada Kantor Pertanahan dalam lingkungan Kanwil Badan
Pertanahan Nasional Propinsi Jawa Barat adalah tinggi

2. Ada pengaruh motivasi kerja terhadap kinerja pegawai.

\section{METODE PENELITIAN}

\section{Metode Yang Digunakan}

Sesuai dengan tujuan penelitian yang telah dirumuskan maka penelitian ini bersifat deskriptif dan verifikatif. Sehubungan dengan jenis penelitian ini, maka metode penelitian yang digunakan adalah metode survey.

Secara sistematis desain atau rencana penelitian disajikan pada Tabel 2 berikut:

Tabel 2. Desain Penelitian yang Digunakan

\begin{tabular}{|l|l|l|l|l|l|}
\hline $\begin{array}{l}\text { Tuj } \\
\text { uan } \\
\text { Ke }\end{array}$ & $\begin{array}{l}\text { Sifat } \\
\text { Pene } \\
\text { litian }\end{array}$ & $\begin{array}{l}\text { Jenis } \\
\text { Inves } \\
\text { tigasi }\end{array}$ & $\begin{array}{l}\text { Ren } \\
\text { tang } \\
\text { Wa } \\
\text { ktu }\end{array}$ & $\begin{array}{l}\text { Hipo } \\
\text { tesis }\end{array}$ & $\begin{array}{l}\text { Anal } \\
\text { isis } \\
\text { Data }\end{array}$ \\
\hline 1 & $\begin{array}{l}\text { Desk } \\
\text { riptif }\end{array}$ & $\begin{array}{l}\text { Deskr } \\
\text { iptif }\end{array}$ & $\begin{array}{l}\text { Cros } \\
\text { s } \\
\text { secti } \\
\text { on } \\
\text { atau } \\
\text { studi } \\
\text { satu } \\
\text { taha } \\
\text { p }\end{array}$ & $\begin{array}{l}\text { Desk } \\
\text { riptif } \\
\text { hipot } \\
\text { esis }\end{array}$ & $\begin{array}{l}\text { Desk } \\
\text { riptif } \\
\text { anali } \\
\text { sis }\end{array}$ \\
\hline 2 & $\begin{array}{l}\text { Verif } \\
\text { ikatif }\end{array}$ & $\begin{array}{l}\text { Kaus } \\
\text { alitas }\end{array}$ & $\begin{array}{l}\text { Cros } \\
\text { s } \\
\text { secti } \\
\text { on } \\
\text { atau } \\
\text { studi } \\
\text { satu } \\
\text { taha } \\
\text { p }\end{array}$ & $\begin{array}{l}\text { Desk } \\
\text { riptif } \\
\text { hipot } \\
\text { esis }\end{array}$ & $\begin{array}{l}\text { Infer } \\
\text { ensia } \\
1 \\
\text { anali } \\
\text { sis }\end{array}$ \\
& & & \\
\hline
\end{tabular}

Populasi dan Sampel Penelitian.

Dengan memperhatikan tujuan penelitian serta ruang lingkup penelitian, maka populasi di dalam penelitian ini adalah seluruh unit elementer yang terdaftar di dalam populasi yang berasal dari gambaran sampel (Sekaran, 2006:266). Dengan demikian populasi sasaran dalam penelitian ini adalah kumpulan data unit elementer yakni para 
pegawai pelaksana dari duapuluhenam Kantor Pertanahan di wilayah kerja Kanwil Badan Pertanahan Nasional Provinsi Jawa Barat .

Karena data dalam penelitian ini menggunakan Structural Equation Modeling (SEM), maka ukuran sampel untuk keperluan ini paling sedikit 5-10 kali banyaknya jumlah parameter. Untuk penelitian yang menggunakan SEM, maka minimal jumlah sampel sebesar 200 unit (Sumacher, Lomax, 1996 : 50; Ferdinan, 2000:48). , peneliti menetapkan besarnya sampel (u) $n=216$ responden

Dari 26 Kantor Pertanahan di Wilayah Kantor Wilayah Badan Pertanahan Nasional Provinsi Jawa Barat peneliti mengambil sampel dari 26 Kantor Pertanahan secara proporsional dari pegawai golongan II s.d III ( pegawai pelaksana ) dengan rumus $n_{i}=$ $\frac{\mathrm{Xi}}{2350} \times 216$

\section{Sumber dan Jenis Data}

Terdapat duavariabel dalam penelitian ini dimana sumber dan jenis data berbeda satu sama lain. Data motivasi kerja bersumber dari pegawai Kantor Pertanahan dengan menjawab kuesioner yang telah disediakan. dan pegawai yang dinilai dan data kinerja bersumber dari pegawai Kantor Pertanahan tetapi kuesioner diisi oleh atasan mereka.

\section{Metode danTeknik Pengumpulan Data}

Data yang diperlukan dalam penelitian ini terdiri dari data primer dan data sekunder. Data primer yang diperlukan dalam penelitian ini dikumpulkan dengan melakukan penelitian lapangan yaitu langsung ke Kantor Pertanahan di lingkungan Kantor Wilayah Badan Pertanahan Nasional Propinsi Jawa BaraT. Sedangkan data sekunder dikumpulkan melalui penelitian kepustakaan/ dokumentasi.

Metode Analisis Data

Pengolahan data yang terkumpul dari hasil penyebaran kuesioner dan pengumpulan data sekunder dilakukan dalam 4 tahap yaitu editing, entry, tabulasi dan analisis data. Mengingat model dalam penelitian ini adalah model kausalitas (hubungan/pengaruh sebab akibat), maka untuk menguji hipotesis yang diajukan digunakan alat uji Model Persamaan Struktural (Structural Equation Model-SEM).

\section{Rancangan Pengujian Hipotesis}

Berdasarkan paradigma dan hipotesis penelitian yang telah diuraikan sebelumnya, dalam penelitian ini terdapat satu variabel eksogen, yaitu: Motivasi kerja (MK), dan satu variabel endogen, yaitu: Kinerja Pegawai (KP). Selanjutnya masing-masing variabel tersebut akan dilakukan pengujian hipotesis secara empiris dengan menggunakan alat analisis Structural Equation Modelling (SEM) melalui penggunaan software Lisrel Version 8.5.

Model rancangan pengujian hipotesis yakni, eratnya hubungan antar variabel independen, besarnya pengaruh variabel independen terhadap variabel dependen dan uji signifikan yang direpresentasikan oleh $\Gamma, \square_{\mathrm{y}}, \square_{\mathrm{x}}$ yang dapat diperoleh melalui program linier. untuk menguji hipotesis di atas digunakan uji t, sehingga pada saat taraf alpa $=5 \%$ maka tolak $\mathrm{H}_{0}$ apabila $\mathrm{t}_{\text {hitung }}>$ $\mathrm{t}$ tabel, berarti model signifikan dan ada data pengaruh.

\section{Hipotesis :}

Motivasi kerja (MK) berpengaruh terhadap Kinerja pegawai (KP)

Struktur ini menggunakan uji statistik hipotesis operasional yang berbentuk:

Ho : semua $\square=0 \mathrm{H} 1$ : ada $\square \square \square 0$ 


\section{HASIL PENELITIAN DAN PEMBAHASAN}

\section{Profil kantor pertanahan di lingkungan kantor wilayah badan pertanahan nasional provinsi jawa barat.}

Upaya peningkatan kinerja lembaga pemerintah seperti Badan Pertanahan Nasional sebagai salah satu alternatif untuk menyikapi serta memenuhi tuntutan masyarakat dalam pelaksanaan pelayanan publik di bidang pertanahan.

Penyelesaian penerbitan sertifikat hak atas tanah tersebut dikerjakan atau diterbitkan oleh lembaga pemerintah yakni Badan Pertanahan Nasional, yang melayani masyarakat seluruh wilayah negara Republik Indonesia dengan perangkat organisasi vertikal didaerah yaitu Kantor Wilayah Badan Pertanahan Nasional Provinsi dan Kantor Pertanahan Kabupaten/Kota dengan mengacu kepada ketentuan peraturan perundang undangan yang berlaku.

\section{Deskripsi Tanggapan Responden Tentang Motivasi Kerja \\ Motivasi kerja pegewai terdiri} atas 19 item pernyataan yang terbagi dalam tiga sub variabel yaitu: kebutuhan untuk berprestasi (need for achievement); Kebutuhan untuk bekerja sama dengan orang lain (need for affiliation), dan kebutuhan untuk memperoleh kekuasaan (need for power). Rekapitulasi skor Motivasi Kerja pegawai dapat dilihat pada Tabel 3

Pada Tabel 3 tersebut di atas memberikan gambaran bahwa paling banyak responden memiliki skor motivasi kerja pegawai dengan skor 4 yaitu sebesar 46,6\%; artinya mayoritas pegawai memiliki motivasi kerja masuk kategori tinggi. Bila ditinjau berdasarkan sub variabel, paling banyak pegawai memiliki kebutuhan yang cukup tinggi untuk kebutuhan berprestasi (skor $3=$ 39,6\%). Pada kebutuhan untuk bekerjasama dengan orang lain, mayoritas pegawai memiliki kebutuhan yang tinggi (skor $4=79,3 \%$ ). Sementara pada kebutuhan untuk memperoleh kekuasaan, sebanyak 48,2\% masuk kategori tinggi dan sebanyak 26,9\% masuk kategori rendah. Hal ini berarti bahwa motivasi kerja pegawai Kantor pertanahan di lingkungan kantor wilayah badan pertanahan nasional Provinsi jawa barat masih perlu untuk ditingkatkan lagi agar di masa mendatang dapat mencapai kategori tinggi, bahkan sangat tinggi terutama dalam hal kebutuhan untuk memperoleh kekuasaan.

\section{Deskripsi Tanggapan Responden Tentang KinerjaPegawai}

Kinerja pegawai diukur terdiri atas 7 item pernyataan yang terbagi dalam 5 (lima) sub variabel yaitu:

Tabel 3. Rekapitulasi Tanggapan Responden Mengenai Motivasi Kerja

\begin{tabular}{|l|l|l|l|l|l|l|l|l|}
\hline \multirow{2}{*}{ Sub Variabel } & \multicolumn{6}{|l|}{ Distribusi Skor Tanggapan Responden } & \multirow{2}{*}{ Total } \\
\cline { 2 - 8 } & \multicolumn{2}{|l|}{$\mathbf{5}$} & $\mathbf{4}$ & $\mathbf{3}$ & $\mathbf{2}$ & $\mathbf{1}$ & \\
\hline \hline \multirow{2}{*}{ Kebutuhan untuk berprestasi } & $\mathrm{F}$ & 292 & 1207 & 1215 & 351 & 1 & 3066 \\
& $\%$ & $9,5 \%$ & $39,4 \%$ & $39,6 \%$ & $11,4 \%$ & $0,0 \%$ & $100 \%$ \\
\hline \multirow{2}{*}{ Kebutuhan untuk bekerjasama dengan orang lain } & $\mathrm{F}$ & 112 & 521 & 23 & 1 & 0 & 657 \\
& $\%$ & $17,0 \%$ & $79,3 \%$ & $3,5 \%$ & $0,2 \%$ & $0,0 \%$ & $100 \%$ \\
\hline \multirow{2}{*}{ Kebutuhan untuk memperoleh kekuasaan } & $\mathrm{F}$ & 29 & 211 & 53 & 118 & 27 & 438 \\
& $\%$ & $6,6 \%$ & $48,2 \%$ & $12,1 \%$ & $26,9 \%$ & $6,2 \%$ & $100 \%$ \\
\hline \hline Motivasi Kerja & $\mathrm{F}$ & $\mathbf{4 3 3}$ & $\mathbf{1 9 3 9}$ & $\mathbf{1 2 9 1}$ & $\mathbf{4 7 0}$ & $\mathbf{2 8}$ & $\mathbf{4 1 6 1}$ \\
& $\%$ & $\mathbf{1 0 , 4 \%}$ & $\mathbf{4 6 , 6 \%}$ & $\mathbf{3 1 , 0 \%}$ & $\mathbf{1 1 , 3 \%}$ & $\mathbf{0 , 7 \%}$ & $\mathbf{1 0 0 \%}$ \\
\hline
\end{tabular}


quantity of work (Jumlah pekerjaan), quality of work (Kualitas pekerjaan), , timeliness(Ketepatan waktu), cost effectiveness (efektivitas baiya) dan need for supervision (Keperluan atas pengawasan). Rekapitulasi skor kinerja pegawai dapat dilihat pada Tabel 4 menyebarkan kuesioner kepada 219 responden yang merupakan pegawai kantor pertanahan di lingkungan kantor wilayah badan pertanahan nasional provinsi jawa barat. Variabel penelitian terdiri atas 2 (dua) variabel laten yaitu (satu variabel exogenus yakni motivasi kerja dan satu variavel endogenus yakni

Tabel 4. Rekapitulasi Tanggapan Responden Tentang Kinerja Pegawai

\begin{tabular}{|c|c|c|c|c|c|c|c|}
\hline \multirow[t]{2}{*}{ Sub Variabel } & & \multicolumn{2}{|c|}{$\begin{array}{l}\text { Distribusi } \\
\text { Responden } \\
\end{array}$} & \multirow{2}{*}{$\begin{array}{l}\text { Skor } \\
\mathbf{3} \\
\end{array}$} & \multicolumn{2}{|c|}{ Tanggapan } & \multirow[t]{2}{*}{ Total } \\
\hline & & 5 & 4 & & 2 & 1 & \\
\hline \begin{tabular}{|l} 
Quantity of work \\
(Jumlah pekerjaan)
\end{tabular} & $\mathrm{F}$ & $\begin{array}{l}17 \\
7,8 \% \\
\end{array}$ & \begin{tabular}{|l|}
44 \\
$33,8 \%$ \\
\end{tabular} & $\begin{array}{l}95 \\
43,4 \% \\
\end{array}$ & \begin{tabular}{|l|}
33 \\
$15,1 \%$ \\
\end{tabular} & $\begin{array}{l}0 \\
0,0 \% \\
\end{array}$ & $\begin{array}{l}219 \\
100 \% \\
\end{array}$ \\
\hline $\begin{array}{l}\text { Quality of work } \\
\text { (Kualitas pekerjaan) }\end{array}$ & $\mathrm{F}$ & $\begin{array}{l}45 \\
10,3 \%\end{array}$ & $\begin{array}{l}391 \\
89,3 \%\end{array}$ & $2,0,5 \%$ & $\begin{array}{l}0 \\
0,0 \% \\
\end{array}$ & $0,0 \%$ & $\begin{array}{l}438 \\
100 \%\end{array}$ \\
\hline Timeliness(Ketepatan waktu) & $\begin{array}{l}\mathrm{F} \\
\%\end{array}$ & $\begin{array}{l}10 \\
2,3 \% \\
\end{array}$ & \begin{tabular}{|l|}
103 \\
$23,5 \%$ \\
\end{tabular} & $\begin{array}{l}282 \\
64,4 \% \\
\end{array}$ & $\begin{array}{l}43 \\
9,8 \% \\
\end{array}$ & $\begin{array}{l}0 \\
0,0 \% \\
\end{array}$ & $\begin{array}{l}438 \\
100 \% \\
\end{array}$ \\
\hline Cost efektiveness (Efektivitas biaya) & $\begin{array}{l}\mathrm{F} \\
\%\end{array}$ & $\begin{array}{l}35 \\
16,0 \% \\
\end{array}$ & \begin{tabular}{|l|}
181 \\
$82,6 \%$ \\
\end{tabular} & $\begin{array}{l}3 \\
1,4 \% \\
\end{array}$ & $\begin{array}{l}0 \\
0,0 \% \\
\end{array}$ & $\begin{array}{l}0 \\
0,0 \%\end{array}$ & $\begin{array}{l}219 \\
100 \% \\
\end{array}$ \\
\hline Need for supervision (Keperluan atas pengawasan) & F & $\begin{array}{l}24 \\
11,0 \% \\
\end{array}$ & $\begin{array}{l}185 \\
84,5 \% \\
\end{array}$ & $\begin{array}{l}4 \\
1,8 \% \\
\end{array}$ & $\begin{array}{l}6 \\
2,7 \% \\
\end{array}$ & $\begin{array}{l}0 \\
0,0 \% \\
\end{array}$ & $\begin{array}{l}219 \\
100 \% \\
\end{array}$ \\
\hline Kinerja Pegawai & $\mathbf{F}$ & $\begin{array}{l}131 \\
8,5 \% \\
\end{array}$ & $\begin{array}{l}934 \\
60,9 \%\end{array}$ & \begin{tabular}{|l|}
386 \\
$25,2 \%$
\end{tabular} & $\begin{array}{l}82 \\
5,3 \% \\
\end{array}$ & $\begin{array}{l}0 \\
\mathbf{0 , 0} \%\end{array}$ & $\begin{array}{l}1533 \\
100 \%\end{array}$ \\
\hline
\end{tabular}

Pada Tabel 4 tersebut di atas memberikan gambaran bahwa skor kinerja pegawai dengan nilai persentase masuk kategori tinggi (skor 4) yaitu sebesar $60,9 \%$. Hal ini berarti bahwa kinerja pegawai Kantor Pertanahan di Lingkungan Kantor Wilayah Badan Pertanahan Nasional Provinsi Jawa Barat masih perlu untuk ditingkatkan lagi agar di masa mendatang mayoritas atau bahkan semua pegawai dapat mencapai kinerja kategori tinggi.

\section{Pengaruh Motivasi kerja Terhadap Kinerja Pegawai}

Untuk mengetahui dan menguji pengaruh antar variabel penelitian motivasi kerja dan kinerja pegawai) dalam penelitian ini dilakukan melalui analisis statistik menggunakan Structural Equation Modelling (SEM). Data yang digunakan diperoleh dengan kinerja pegawai ).

Berdasarkan data yang diperoleh dari hasil penyebaran kuesioner mempunyai skala pengukuran ordinal, estimasi nilai loading setiap dimensi variabel penelitian dan koefisien pengaruh antar variabel penelitian dilakukan dengan bantuan Software Lisrel 8.5.

Hasil estimasi loading faktor beserta uji t dalam Path Diagram Model persamaan struktural disajikan pada Gambar 1

\section{Hasil Estimasi Loading Faktor Pembentuk Variabel Penelitian (Hasil Perhitungan Model Pengukuran)}




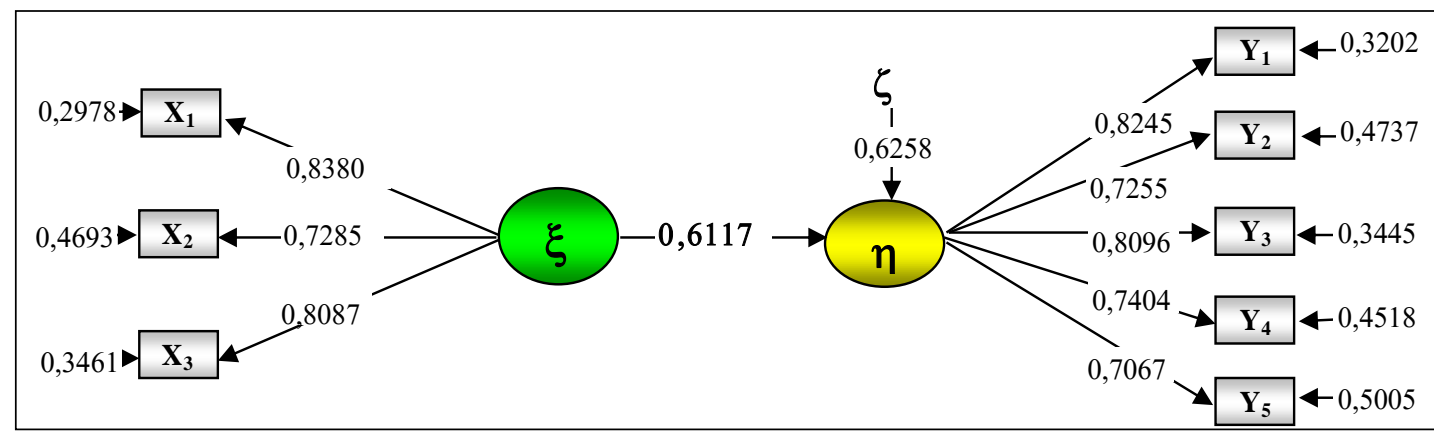

Gambar 1 Path Diagram Model Persamaan Struktural

Untuk mengetahui apakah loading faktor yang digunakan dalam masing-masing variabel laten pada model Motivasi kerja $\left(\xi_{1}\right)$ dan Kinerja Pegawai $(\boldsymbol{\eta})$ telah memiliki derajat kesesuaian yang baik, terlebih dahulu dilakukan uji reliabilitas menggunakan pendekatan cunstruct reliability dan variance extracted serta uji signifikansi untuk setiap loading faktor pembentuk variabel dengan uji t.

\section{1) Hasil Estimasi Loading Faktor} Pembentuk Variabel Motivasi $\operatorname{Kerja}\left(\xi_{2}\right)$

Hasil estimasi model pengukuran variabel Motivasi Kerja $\xi_{2}$ )dapat dilihat pada tabel 5 sebagai berikut.
Pada Tabel 5 di atas terlihat nilai $\mathrm{t}$ hitung untuk setiap indikator variabel laten Motivasi Kerja ( $\xi$ ) lebih besar dari 1,96 yang menunjukkan bahwa semua indikator yang digunakan signifikan dalam membentuk variabel laten Motivasi Kerja ( $\xi$ ).

Berdasarkan loading faktor yang diperoleh untuk indikator yang membentuk variabel laten Motivasi Kerja dapat dilihat indikator kebutuhan untuk berprestasi $(0,8380)$ memiliki bobot faktor paling besar di antara 2 faktor lainnya dan diikuti dengan kebutuhan untuk memperoleh kekuasaan $(0,8087)$, dan yang terkecil kebutuhan untuk bekerja sama dengan orang lain $(0,7285)$.

Tabel 5. Ringkasan Hasil Komputasi Model Pengukuran

Variabel Laten Motivasi Kerja ( $\left.\xi_{2}\right)$

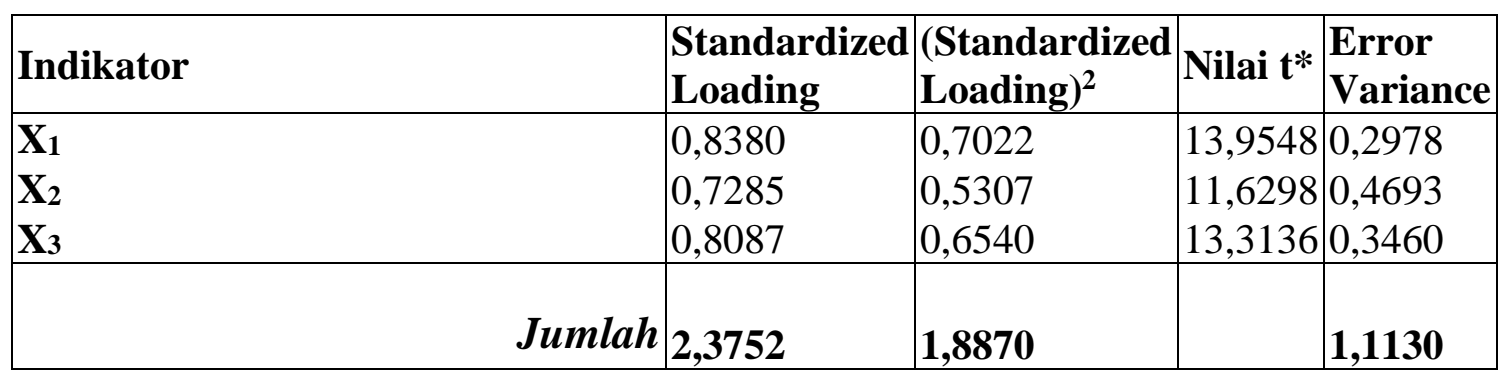

Construct Reliability $=\mathbf{0 , 8 3 5 2}$

Variance Extracted $=0,6290$

$* \mathrm{t}$-kritis $=1,96$ 
2) Hasil Estimasi Loading Faktor Pembentuk Variabel Kinerja Pegawai $(\eta)$

Hasil estimasi model pengukuran variabel Kinerja Pegawai $(\eta)$ dapat dilihat pada tabel 6 berikut. menjadi satu bagian, yakni: 1) Pengujian hipotesis merupakan pengujian pengaruh positif motivasi kerja terhadap kinerja pegawai, yang diuji dengan Gambar diagram jalur model lengkap (full model) persamaan struktural pada Gambar di atas.

Tabel 6. Ringkasan Hasil Komputasi Model Pengukuran

Variabel Laten Kinerja Pegawai ( $\eta$ )

\begin{tabular}{|c|c|c|c|c|}
\hline Indikator & \begin{tabular}{|l|} 
Standardized \\
Loading
\end{tabular} & $\begin{array}{l}\text { (Standardized } \\
\text { Loading) }^{2}\end{array}$ & Nilai $t^{*}$ & \begin{tabular}{|l|} 
Error \\
Variance
\end{tabular} \\
\hline$\overline{Y_{1}}$ & 0,8245 & 0,6798 & & 0,3202 \\
\hline $\mathbf{Y}_{2}$ & 0,7255 & 0,5264 & 11,4580 & 0,4736 \\
\hline $\mathbf{Y}_{3}$ & 0,8096 & 0,6555 & 13,1551 & 0,3445 \\
\hline$Y_{4}$ & 0,7404 & 0,5482 & 11,7565 & 0,4518 \\
\hline$Y_{5}$ & 0,7067 & 0,4994 & 11,0874 & 0,5006 \\
\hline & 3,8067 & 2,9092 & & 2,0908 \\
\hline
\end{tabular}

Construct Reliability $=\mathbf{0 , 8 7 3 9}$

Variance Extracted = 0,5818

$*$ t-kritis $=1,96$

Berdasarkan hasil perhitungan tersebut dapat dilihat bahwa nilai hasil estimasi model pengukuran menunjukkan seluruh variabel observabel bermakna karena indikator yang digunakan semuanya signifikan dalam membentuk variabel laten Motivasi Kerja $\left(\xi_{1}\right)$ dan Kinerja Pegawai $(\eta)$

\section{Hasil Perhitungan Model Struktural dan Pengujian Hipotesis}

Setelah diperoleh hasil seluruh indikator signifikan pada model pengukuran untuk setiap variabel laten yang digunakan, selanjutnya dapat dilihat hasil model struktural untuk menjawab hipotesis yang diajukan.

Pengujian hipotesis berikut ini sejalan dengan model persamaan structural yang mengintegrasikan hasil perhitungan berupa koefisien korelasional dan pengaruh antar variabel yang diuji. Jadi hasil persamaan structural ini terbagi

\section{Pengaruh Motivasi Kerja $\left(\xi_{1}\right)$ Terhadap Kinerja pegawai $(\eta)$}

Hipotesis dalam penelitian ini adalah: Motivasi kerja berpengaruh terhadap Kinerja pegawai.

Koefisien pengaruh variabel Motivasi $\operatorname{Kerja}\left(\xi_{2}\right)$ terhadap kinerja pegawai $(\eta)$ sebesar 0,3742 dengan nilai $\mathrm{t}_{\text {hitung }}$ untuk uji statistik sebesar 8,0506. Ringkasan hasil perhitungan model struktural dapat dilihat pada Tabel 7

Untuk menguji pengaruh variabel yang dihipotesiskan di atas digunakan uji t dengan kriteria uji untuk $\square \square \square$ penelitian sebesar $\square 0,05$, nilai untuk batas dinyatakan signifikan adalah 1,96. Hasil perbandingan antara $t_{\text {hitung }}$ dengan $\mathrm{t}$ tabel untuk uji parsial dapat dilihat pada Tabel 8 
Tabel 7. Hasil Perhitungan Model Struktural Pengaruh Motivasi Kerja $\left(\xi_{1}\right)$ Terhadap Kinerja Pegawai $(\eta)$

\begin{tabular}{|l|l|l|l|l|l|l|}
\hline $\begin{array}{l}\text { Variabel } \\
\text { Laten } \\
\text { Endogen }\end{array}$ & $\begin{array}{l}\text { Variabel } \\
\text { Laten Eksogen }\end{array}$ & $\begin{array}{l}\text { Koefisien } \\
\text { Jalur }\end{array}$ & $\begin{array}{l}\text { Standard } \\
\text { Error }\end{array}$ & t-hitung & $\mathbf{R}^{\mathbf{2}}$ & $\begin{array}{l}\text { Error } \\
\text { Variance }\end{array}$ \\
\hline \hline $\begin{array}{l}\text { Kinerja } \\
\text { Pegawai } \\
(\eta)\end{array}$ & Motivasi Kerja $(\xi), 0,6117$ & 0,0760 & 8,0506 & 0,3742 & 0,6258 \\
\cline { 2 - 6 } & & & & & & \\
\hline
\end{tabular}

Sumber: Output Lisrel

Tabel 8. Uji Hipotesis Pengaruh Secara Parsial Motivasi Kerja ( $\xi$ )Terhadap Kinerja Pegawai $(\eta)$

\begin{tabular}{|l|l|l|l|l|l|l|}
\hline No & Hipotesis & $\begin{array}{l}\text { Koefisien } \\
\text { Jalur }\end{array}$ & thitung & ttabel & Hasil & Kesimpulan \\
\hline 1 & $\begin{array}{l}\text { Motivasi Kerja }(\xi \\
\text { berpengaruh } \\
\text { terhadap Kinerja } \\
\text { pegawai } \eta)\end{array}$ & 0,6117 & 8,0506 & 1,96 & $\begin{array}{l}\text { Uji } \\
\text { Signifikan }\end{array}$ & $\begin{array}{l}\mathrm{H}_{0} \text { ditolak, terdapat } \\
\text { pengaruh Motivasi } \\
\text { Kerja }(\xi) \text { terhadap } \\
\text { kinerja pegawai }(\eta \\
\end{array}$ \\
\hline
\end{tabular}

Sumber: Hasil Pengolahan Data Penelitian,2008.

Jadi dapat disimpulkan pengaruh Motivasi Kerja $(\xi)$ terhadap kinerja pegawai $(\eta)$ signifikan secara pengujian statistik karena nilai $\mathrm{t}_{\text {hitung }}$ untuk setiap pengujian lebih besar dari $t_{\text {tabel }} 1,96$. Atau dengan kata lain, pengaruh Motivasi Kerja $(\xi)$ terhadap kinerja pegawai $(\eta$ )nilai $\mathrm{t}$ hitung $8,0506>\mathrm{t}$ tabel 1,965 dengan demikian dapat disimpulkan pengaruh Motivasi Kerja ( $\xi)$ terhadap kinerja pegawai $(\eta)$ adalah signifikan.

Berdasarkan hasil perhitungan diperoleh total pengaruh Motivasi Kerja $(\xi)$ terhadap kinerja pegawai $(\eta)$ adalah sebesar $0,3742(37,42 \%)$ dan pengaruh faktor lain sebesar 0,6258 (62,58\%).

Pegawai yang mempunyai motivasi kerja tinggi pada suatu kantor adalah Pegawai yang paham pada pekerjaannya, sungguh-sungguh dalam bekerja, setia pada organisasi dan mempunyai motivasi tinggi dalam bekerja. (Chohen, 1999). Hal ini secara langsung dapat meningkatkan manfaat kualitas kinerja pegawai yang diterima masyarakat pemohon sertifikat hak atas tanah, sehingga akan dapat meningkatkan kinerja pegawai.

\section{Implikasi Hasil Pengujian Hipotesis Kedua:Pengaruh Motivasi Kerja Berpengaruh Terhadap Kinerja Pegawai Pegawai Kantor pertanahan Implikasi hasil pengujian} hipotesis dari temuan penelitian ini dapat ditinjau dari sudut pandang teori sumber daya manusia dan manajerial. Dari sudut pandang teori sumber daya manusia temuan penelitian ini menunjukkan bahwa Motivasi memainkan peran yang signifikan dalam menjelaskan Kinerja pegawai kantor pertanahan. Temuan ini membuktikan bahwa para perencana sumber daya manusia pada Kantor pertanahan perlu memperhatikan 
Motivasi Kerja dalam membangun Kinerja Pegawai.

Dari sudut pandang manajerial, hasil penelitian menunjukkan bahwa semakin tinggi Motivasi Kerja, maka semakin meningkat Kinerja Pegawai. Dengan Motivasi Kerja berpengaruh terhadap Kinerja Pegawai, maka pihak Pimpinan Kantor pertanahan perlu memperhatikan Motivasi Kerja pegawai dalam membentuk Kinerja Pegawai.

\section{Temuan penelitian.}

Berdasarkan hasil penelitian dan pembahasan yang diuraikan di atas maka dapat dikemukakan beberapa temuan empiris dan teoritis penelitian dari disertasi ini sebagai berikut:

(1). Temuan empiris:

a. Tingkat Motivasi kerja pada kantor pertanahan di lingkungan kantor wilayah badan pertanahan nasional provinsi jawa barat secara rata-rata dalam kategori tinggi. Dimensi Motivasi Kerja yang mencakup Kebutuhan untuk berprestasi dan Kebutuhan untuk bekerja sama dengan orang lain adalah dalam kategori tinggi, sedangkan dimensi Motivasi Kerja yang mencakup Kebutuhan untuk memperoleh kekuasaan dalam kategori cukup tinggi

b. Tingkat Motivasi Kerja berperan dalam meningkatkan Kinerja pegawai kantor pertanahan di lingkungan kantor wilayah badan pertanahan nasional provinsi jawa barat.

(2).Temuan teoritis:

a. Menghasilkan model kausalitas pengaruh Motivasi kerja terhadap Kinerja pegawai

b. Menghasilkan model kausalitas pengaruh Motivasi terhadap Kinerja Pegawai kantor pertanahan di lingkungan kantor wilayah badan pertanahan nasional provinsi jawa barat.
Variabel Lain yang Mempengaruhi Kinerja Kantor pertanahan di lingkungan kantor wilayah badan pertanahan nasional provinsi jawa barat.

c. Berdasarkan hasil penelitian yang telah diuraikan di atas diperoleh bahwa pengaruh langsung variabel independen: Motivasi kerja terhadap Kinerja pegawai sebesar $37,42 \%$ hal ini berarti masih ada pengaruh variabel lain sebesar 62,58\%yang dapat berperan dalam meningkatkan Kinerja Pegawai Kantor pertanahan di lingkungan kantor wilayah badan pertanahan nasional provinsi jawa barat.

\section{E. KESIMPULAN DAN SARAN}

Berdasarkan uraian pembahasan pada bab-bab terdahulu, maka dapat ditarik beberapa kesimpulan dan saran sebagai berikut:

\section{Kesimpulan}

Simpulan berdasarkan analisis deskriptif:

- Secara deskriptif motivasi kerja dapat digambarkan sebagai berikut:

(1) Motivasi kerja Pegawai Pada Kantor Pertanahan di Lingkungan Kantor Wilayah Badan Pertanahan Nasional Provinsi Jawa Barat masih perlu untuk ditingkatkan lagi agar di masa mendatang dapat mencapai kategori sangat tinggi. dilihat dari indikator keinginan berprestasi dan kebutuhan untuk bekerjasama dengan orang lain.Akan tetapi dilihat dari indikator keinginan mempengaruhi orang lain dan orientasi kepada jabatan belum mendukung secara optimal dalam motivasi kerja pegawai yang telah ada saat ini.

(2) Kinerja Pegawai Kantor Pertanahan di Lingkungan Kantor Wilayah Badan Pertanahan Nasional Provinsi Jawa Barat adalah cukup baik dilihat dari indikator kualitas pekerjaan, 
efektivitas biaya dan keperluan atas pengawasan. Akan tetapi dilihat dari indikator kuantitas pekerjaan dan ketepatan waktu masih belum baik.

- Motivasi kerja berpengaruh positif dan signifikan terhadap kinerja pegawai Kantor Pertanahan di Lingkungan Kantor Wilayah Badan Pertanahan Nasional Provinsi Jawa Barat. Hal ini berarti bahwa motivasi kerja berperan dalam mendukung kinerja pegawai.

\section{Saran}

Saran ini meliputi saran akademis bagi peneliti berikutnya dan bagi para pakar manajemen sumber daya manusia dalam rangka pengembangan ilmu serta saran operasional bagi pihak pengambil keputusan pada Kantor pertanahan di lingkungan kantor wilayah badan pertanahan nasional Provinsi jawa barat.

- Saran Pengembangan Ilmu

(1) Secara teoritis, dalam pengembangan ilmu bahwa motivasi kerja berpengaruh terhadap kinerja pegawai.

- Saran Operasional

(1) Berdasarkan hasil analisis deskriptif motivasi kerja dan kinerja pegawai masih tergolong cukup baik, maka kedua variabel ini masih harus ditingkatkan lagi.

(2) Hasil penelitian berdasarkan analisis verifikatif menunjukkan bahwa motivasi kerja berpengaruh terhadap kinerja pegawai Kantor pertanahan di lingkungan kantor wilayah badan pertanahan nasional Provinsi jawa barat. Oleh karena itu, pengambil keputusan Kantor pertanahan di lingkungan kantor wilayah badan pertanahan nasional Provinsi jawa barat harus memperbaiki dalam usaha meningkatkan motivasi kerja pegawai.

\section{DAFTAR PUSTAKA}

Benardine, HJ. \& Russel. 1993. Human Resources Management. Singapore, McGrow-Hill. International Edition. Nawawi, H. Hadari, 1998, Manajemen Sumber Daya Manusia, Bandung : Remaja Rosdakarya

Schumaker, Pandall E. and Richard G. Lomax. 1996. A Beginner's Guide to Structural Equation Modelling. Mahwah, New Jersey : Lawrence Erlbaum Associates, Publishers.

Sekaran Uma. 2003. Research Methods for Business : A Skill Building Approach. $3^{\text {rd }}$ Edition. USA : John Wiley \& Sons, Inc.

\section{Peraturan Pemerintah}

Peraturan Kepala Badan Pertanahan Nasional Republik Indonesia No. 3 tahun 2006 Tentang Organisasi dan Tata Kerja Badan Pertanahan Nasional RI.

Peraturan Kepala Badan Pertanahan Nasional Republik Indonesia No. 4 Tahun 2006 Tentang Organisasi dan Tata Kerja Kantor Wilayah Badan Pertanahan Nasional dan Kantor Pertanahan. 